International Journal of Linguistics, Literature and Culture
Available online at https://sloap.org/journals/index.php/ijllc/
Vol. 7 No. 3, May 2021, pages: 146-151
ISSN: 2455-8028
https://doi.org/10.21744/ijllc.v7n3.1498

\title{
Artistic Interpretation of the Epic Creative Image
}

Jabbor Eshonkulov a

Article history:

Submitted: 9 February 2021

Revised: 27 March 2021

Accepted: 18 April 2021

\section{Keywords:}

artistic interpretation;

bakhshi;

epic creation;

epic tour;

folk epics;

folklore;

oral creation law;

written literature;

\section{Corresponding author:}

Eshonkulov, J.

70, Tashkent 100047, Uzbekistan

Email address: jabbores@yandex.ru

\section{Abstract}

Folklore is a unique art form. It differs from the written literature in its oral, traditional, varied, collective nature. That is, folk epics, which are an example of folklore, have many variants of their own. His text is not stable. These epics, sung by the bakhshis, differ from the epics, which are an example of written literature, in these aspects, that is, in their oral assimilation, oral performance, and oral heritage. These epics change in each performance as they are sung by the performer, the bakhshis. Because bakhshi is based on the law of live performance. Epic art, that is, the epics sung by the bakhshis to understand the essence of the content; it will be necessary to have a fuller understanding of the art of witchcraft. We can learn about the bakhshis from the epics they sang. Epics such as "Alpomish", "Manas", "Gorogly", and the "Book of Dada Korkut" speak of the image of the bakhshi. This article deals with the artistic interpretation of the image of the epic creator in folk epics.

International journal of linguistics, literature and culture (C) 2021. This is an open access article under the CC BY-NC-ND license (https://creativecommons.org/licenses/by-nc-nd/4.0/).

\footnotetext{
${ }^{\text {a }}$ Alisher Navoi State Museum of Literature, Academy of Sciences of the Republic of Uzbekistan, Tashkent, Uzbekistan
} 


\section{Introduction}

Epic creation is the artistic history of every nation. Therefore, its performers are great artists who have preserved the history, art and culture of the nation for thousands of years, passed it down from generation to generation, and have made a unique contribution to the national culture, history and philosophy. Huge artistic monuments such as "Alpomish", "Gorogly", "Manas", "Book of Dada Korkut", "Qoblandi Botir" are also inherited from such epic creators. These epics and other examples of folklore are being studied extensively and comprehensively by our specialists. However, the performer of the epic works himself, i.e. the image of the epic creator, has not yet been sufficiently studied. The reason for this, in my view, is that, first, the main focus is on the historical foundations, epic system, art, and typological analysis of epic works; the second is that the whole epic is considered to be a work of art in which the main protagonist is the creator. However, if we compare the images of "Korkut ota", "Saqibulbul", "Oshiq Gharib", "Oshiq Alband", "Oshiq Mahmud", which are scattered in many epics, we see that they appeared as a synthesis of the ancient ideas and beliefs of the people about bakhshi, ozone, ashiqs - lovers.

In addition, the epic tradition, such as "Olllanazar Olchinbek", "Kor Ghoyib", which has hitherto escaped the attention of researchers, but has played an important role in Uzbek folklore; the existence of separate epic works in which the image of the creator is central requires a more in-depth study of the subject. Not because "Ollanazar Olchinbek" was the main protagonist in the epics "Kor Ghoyib", but because of the epic tradition of the people, the teacher-student relationship; the process of formation of the bakhshi and his life; the viability of the live oral performance process is also significant in that it has found its full artistic expression.

\section{The Main Findings and Results}

It is known that when we say epic creators, we mean Bakhshi (ozan, aqin, jirov, saqi - wine-server, sozchi musician, yuzboshi - a man who controls hundred people, sannovchi - calculator and so on) (Jirmunsky, 1947; Mirzaev, 1979; Köprülü, 1989), Khalfas (individual khalfas, collective khalfas), storytellers, narrators, storytellers. Although a common feature of these artists is creativity, bakhshis play a special role in the preservation of epic works from generation to generation. In turn, the bakhshis are also local features of a particular region (for example, in Uzbekistan a) Southern region - Surkhandarya, Kashkadarya, Samarkand, Jizzakh, Syrdarya; b) Central region Tashkent region and valley; c) Khorezm) and performance instruments (1. Drum. 2. Kobiz. 3. Dutor (narrow, gijjak, bolomon), Performance style (1. Singers in the inner voice; 2 . Singers in the outer voice) Performance and poetic skills (1. Creative bakhshis; 2. Executive bakhshis). When talking about an epic creator, these aspects should be taken into account.

The history of the art of speech, one of the greatest inventions of mankind, is very ancient, and its first roots go back to the history of folklore of the peoples of the world, that is, the transformation of non-aesthetic phenomena into aesthetic phenomena in the history of word art. We see the first non-aesthetic roots of word art in the history of folklore of all peoples of the world (Jirmunsky, 1979; Grinzer, 1979; Link, 1980). The transition of the people from mythological thinking to poetic comprehension and the resulting folklore heritage in the modern sense is so complex that in some examples it can be seen from the traces of primitive society and subsequent early cultural stages to modern poetic observations and artistic expressions.

The history, art, artistic and aesthetic significance of works in the art of oral speech, from the smallest genre of proverbs to the largest epic genres, is primarily associated with the work of its creative people and its mature representatives, including professional folk singers. The word Bakhshi has many meanings: an artist, a master, a priest, a priest, an enlightened, a guide, a surgeon, a secretary, who memorizes national and epic poems and passes them down from generation to generation. In the image of the epic artist in artistic creation, however, many of the above features come in a mixture. This shows that the system of perceptions about these artists has its ancient roots (McCain, 2006).

In each story of the "Book of Dada Korkut", "Korkut ota is played as the main character: "Dedem Korkut boy boyladi soz soyladi" (Dede Korkut kitabi, 1994), "Dedem Korkut geldi sadilik caldi boy boyladi soy soyladi? (Dede Korkut kitabi, 1994) Gazi erenler basina ne geldigini soyladi" (Dede Korkut kitabi, 1994). The mythological notions about the Korkut father, the patriarch, the guide, and at the same time the epic creator, prove one thing: bakhshi and shaman are in fact different manifestations of a syncretic image in different eras.

Eshonkulov, J. (2021). Artistic interpretation of the epic creative image. International Journal of Linguistics, Literature and Culture, 7(3), 146-151. https://doi.org/10.21744/ijllc.v7n3.1498 
Such evolutions have played an important role in the development of epic consciousness, which is the source of the nation's history, heroic past, and spirituality. The magical aspects of the epic gradually faded, and the functions of shaman, doctor, baxshi, and guide became more and more different: “... A man named Korkut ota was born from the descendants of Bayot. He was a complete connoisseur of Oguz. Inside the ox, all his miracles were manifested. What can be said, there were various reports about the disappearance" (Dede Korkut kitabi, 1994). So, he is the leader of the nation, the wise man, the hero. But he is a huge epic creator who embodies the image of a patriarch shaman in the first place (Rohrer, 2005). His greed is also due to the fact that he is able to tell secrets from the unseen. "Dedem Korkut geluben sazilik caldi, bu Oguz-nameyi duzdi kosdi, boyle dedi" (Dede Korkut kitabi, 1994). So, "geluben sazilik caldi" - continued the epic tradition, "duzdi kosdi" - demonstrated that he was not a performer, but a creative genius, "boyle dedi" - left a legacy for future generations.

Muharram Ergun, who in his research paid special attention to the qualities of Korkut's generosity, writes: "Bu ise Dede Korkutun Dede Korkut kitabindeki ozan ve gaipten haber verme sifatlarina bastanbasa uygundur" (Ergun, 1994; Beech et al., 2012). Again: The sentences "Dede Korkut dilinden ozan aydur" in "Dede Korkut kitabi" emphasize the fact that this monument is an example of an epic tradition, on the one hand, and on the other hand, in the epic Korkut embodies the image of other bakhshis who considered their father as a pir and a teacher (Dede Korkut kitabi, 1994).

The most archaic examples of the epic artist in Uzbek folklore are the image of Saqibulbul in the series of epics "Gorogly" and Gorogly himself (Birth of Gorogly, 1967). In addition to Gorogly's heroic invincible battle, he is a mag, just like Father Korkut; that both the shaman and the master of words were bakhshis, that he was sponsored by Hizr and the chiltons; we see that Hizr himself appointed Saqibulbul as both a teacher and a servant to him. In a word, as a holistic image, Gorogly generalized the features of all historical types of folk epic creators.

One of the characters in the epics that proves Gorogly's shamanism and generosity is Saqibulbul. In the epic "Birth of Gorogly" Saqibulbul Gorogly will have both a teacher and a number appointed by the elders. At the same time, he is a musician, a singer, that is, a bakhshi. It is the epic image of a syncretic melody, directly connected with the mythological worldview. So, he concludes that he was a teacher who taught Gorogly both to fight and to sing (Birth of Gorogly, 1967).

The word "Soqi" has two meanings, both of which correspond to the image of Saqibulbul. The first meaning "bakhshi" - means "poet". The second represents the meaning of "kosagul", "davraboshi", "wine-server" (Annotated dictionary of the Uzbek language, 1981). Blessings and shamanism are added to the drink of Saqibulbul. So, he is not a simple, narrow-minded bakhsh. We must not forget that the symbolic content of the ancient religious rites is more important than the material may, such as "may", "tavern", "drinking wine", "journey cup" in the epic. The "tavern" was a place of worship, and the "saqi" was a priest who conducted the prayer. A third meaning of the word "saqi', which is forgotten today, corresponds to the word 'priest'. In the Gorogly epics, Saqibulbul was the chief priest and chief shaman. He gave the hero a "white blessing" as he set off before the journey. So, Saqibulbul is a multifaceted image formed on the basis of pre-Islamic worldviews. Logically, it was natural that the folk bakhshis, who loved to sing Gorogly's epics, incorporated into this image the peculiarities of the mytho-poetic ideas about themselves and bakhshism. Not only Saqibulbul, but also the poet Hannon in the presence of Urayhan in the epic of the birth of Gorogly. According to the epic, Hannon, who greeted the visitor with words, looked at Gorogly with the poet's good manners:

Soling shertgan sozlarga!dono qaragan

Mahbus okil ayamiz chertib, (Birth of Gorogly: 1967, p. 81-86)

Listen to the words you click tonight!

We play the song and sing in the evening, -

The principles of the people's bakhshis, that is, to please people with words, to recite songs and epics at night, were reflected in his appeals.

In addition, in the history of the mytho-poetic interpretation of the epic bakhshi in Uzbek folklore, we see the images of Khojai Hizr, Bobo Qambar, Mulla Goyib, Oshiq Aydin, Ollanazar Olchinbek as their patrons and teachers.

Khoja Hizr is one of the most ancient mythological images of Uzbek folk epics and legends, which, in addition to imparting the gift of goodness in the dream, gives food to the heroes and people of the epic, the state, happiness. Other epic characters, who considered the Prophet Khidr a teacher, are also considered pir. In particular, the narration of the poet Fazil about the blind Ghoib contains the following verses: 
Mulla ghoyib says: Xizirim pirim, o'n ikki Imom, chilton erur dastgirim, // jahonning quyuni bo'lganda bordir (Mulla Ghoyib, №1677). Bobo Kambar - According to the epic "Birth of Gorogly", one of the priests sponsored by Gorogly is Bobo Kambar. Kazakh folklorist A. Kanratbaev notes that twelve versions of Kambar Batyr have been recorded, that Kambar was the first shaman of the Turkic-speaking peoples, and that the stories about Bobo Kambar are very ancient (Kanratbaev, 1971; Danahy, 2001).

In Uzbek folklore, Kambar Bobo made the first dutar, in which the legendary figure who first played the melody, the piri of singers and poets, is interpreted as a very skilled musician. Ethnographer V.B. Basilov shows that the genetic roots of mythological views, based on the idea of Kambar as a patron of music and singing, go back to ancient shaman mythology.

Mulla Ghoyib - There are many legends, myths and unfinished epics about him. If the prophet Hizr, Dada Korkut, Bobo Qambar, Gorogli are the mythological patrons and teachers of epic bakhshis, Mullah Ghoib and Oshiq Aydin are historical figures, but they are epic characters in Uzbek folklore. Therefore, in the narration written by Hodi Zarif Fozil Yuldash ogli, he is not a legendary person, but a man of great epic knowledge, a very skillful folk poet. Ashiq Aydin Pir is the patron and mentor of the legendary Khorezm oasis bakhshis in the epic tradition. This image has a historical basis and its tomb is located sixty kilometers southwest of the city of Old Urgench in what is now Turkmenistan. This man, a scholar of poetry and music, died in 1255 . There are many legendary stories about him among the people. But not a single work has arrived. It is generally believed that people who embarked on the path of baxshi should take a blessing from Ashiq Aydin Pir, the lovers who set out on a journey in the epics.

Ollanazar Olchinbek is also a teacher and piri of bakhshis in the southern part of Uzbekistan. There are four versions of the epic of the same name. These are the variants of Eson ota Shomurodov (Mulla Ghoyib, №932), Mardonaqul Avliyokul ogli (Mulla Ghoyib, №1268), Normurod baxshi Poyonov (Mulla Ghoyib, №7319), Qahhor baxshi Qodir ogli (Mulla Ghoyib, №3), and the most perfect of them is Qahhor bakhshi’s.

This epic covers the cult of the bakhshi (topinchi) bakhshi and instrument, teacher and disciple, performer and listener, schools of bakhshi, methods and ways of performance, repertoire and other issues. The protagonist of the epic "Ollonazar - Olchinbek" is the result of mythological and poetic thinking on the historical basis, embodied as a mature folk poet, a perfect man, who has thoroughly mastered the repertoire of South Surkhandarya epic schools, a teacher of forty bakhshis. Since the epic "Ollonazar - Olchinbek" is based on the image of the people's bakhshi, it also has images of other bakhshis, which serve to fully and perfectly portray the protagonist, express the main idea of the epic, ensure the course of events and form the plot of the epic. The protagonist of the epic "Ollonazar Olchinbek" Ollonazar is traditionally an image that has traversed the historical path of epic creativity. Therefore, it is difficult to fully understand the essence of this image without the interpretation of epic bakhshis in the folklore of the Turkic peoples.

\section{Conclusion}

If the above-mentioned epics and the creative images in the "Book of Dada Korkut" and other epic examples are compared; in which we can observe that the following types of bakhshis stand out.

1) Images based on mythological beliefs. Examples of this type are the images of Hizr (Khidr), Dada Korkut, Saqibulbul.

2) Images with a historical basis, but at the same time appropriate to the type of worship: the images of Kor Ghoib, Oshik Aydin, Ollanazar Olchinbek. It is true that in many historical sources, for example, the name of Dada Korkut in Reseduddin's "Camiut-tevarih" ide is mentioned as one of the four Oghuz rulers. Or Alisher Navoi's "Nasayim ul-muhabbat" and "Shajarayi Tarokima" contain information about Korkut. However, perceptions of Korkut's father's epic creativity have more of their own mythological ground. If the fearful father has risen to the level of both a teacher and a pir and mythological patron; Ollanazar Olchinbek, Oshiq Aydinlar could not rise to this level.

3) The type of Bakhshi's image in the interpretation of artistic texture. Images of Oshiq Gharib, Oshiq Mahmud, Oshiq Alband. In this series of epics, the bakhshi (lover) is embodied as the protagonist of an epic work.

Rather, the protagonist of the epic uses his creative ability to achieve his goal, that is, to overcome difficulties. This is especially evident in the epics "Oshiq Gharib va Shohsanam", "Oshiq Mahmud", "Oshiq Alband". All types have common and at the same time different aspects. General aspects: (a) All characters play lyrics, epics and songs. (b) Participate in epic events as a full-fledged artistic image. Special features of these images:

Eshonkulov, J. (2021). Artistic interpretation of the epic creative image. International Journal of Linguistics, Literature and Culture, 7(3), 146-151. https://doi.org/10.21744/ijllc.v7n3.1498 
The first type: the ancient worldview of the Turkic peoples, embodies the notions of the cult of bakhshi in the mythological system. They have a mythological as well as a legendary family tree and destiny. In each of these types of images, the images are reflected to varying degrees. In particular, Hizr sponsors all the bakhshis by giving them the power of bakhsh and other aspects. But his status as a direct benefactor is not clearly stated. Korkut ota and Saqibulbul are fully represented as heroes, advisers, teachers and benefactors. This aspect is especially perfectly reflected in the image of Korkut. Although Saqibulbul is said to be one of the Iranians, Gorogly's number and advisor, baxshizism is his main virtue.

The second type: Representatives of this type of Bakhshi image are actually people who were born and lived in real life, who, thanks to certain patronage forces, have mastered the art of Bakhshi and risen to the level of Bakhshi's prophetic teacher, guide. Their lives and activities became known and popular among the people, became the basis for the weaving of various legends, legends, epics. The third type: This type of image is an artistic tissue image, which has become a symbol of love, a lover. Bakhshi poetry plays an important role in their love and friendship. So, while the image of the first type of bakhshi passed from the mythological basis to the mytho-poetic layer, the second type was taken from the real basis to the mytho-poetic layer, and they assimilate into a certain epic or series and perform their artistic, aesthetic function. Bakhshis of this type are pir, masters of other creators. Although a separate epic has been created about these creators, they only apply within the framework of this epic.

The third type is mainly artistically-aesthetically interpreted in the poetic layer, and they are considered only as lovers. The image of the bakhshi of this type emerged as the center of the ancient notions and imaginations of the bakhshi of the people, the epic creators in general. Therefore, in such a series of epics, the protagonist uses his creative ability to get out of the most difficult situations. In short, this topic is not an article or a study. It needs to be studied in detail, in depth and in detail. We have only touched on some aspects of this huge issue. The interpretation of the image of the epic creator in folklore plays an important role in a more complete understanding of the system of ideas about the art of bakhshi and bakhshi, the nature of folklore of the Turkic world, its peculiarities, the place of the epic about baxshi in the epic tradition, its historical foundations and art.

\section{Conflict of interest statement}

The author declared that (s)he has no competing interest.

Statement of authorship

The author has a responsibility for the conception and design of the study. The author has approved the final article.

\section{Acknowledgments}

I am/We are grateful to two anonymous reviewers for their valuable comments on the earlier version of this paper. 


\section{References}

Annotated dictionary of the Uzbek language. (1981) Two volumes. - Moscow. Volume II.

Beech, N., Gilmore, C., Cochrane, E., \& Greig, G. (2012). Identity work as a response to tensions: A re-narration in opera rehearsals. Scandinavian Journal of Management, 28(1), 39-47. https://doi.org/10.1016/j.scaman.2011.12.005

Birth of Gorogly. (1967) Epics. The narrator is Muhammadqul Jomrot ogli Polkan. - Tashkent: Fiction.

Danahy, J. W. (2001). Technology for dynamic viewing and peripheral vision in landscape visualization. Landscape and Urban Planning, 54(1-4), 127-138. https://doi.org/10.1016/S0169-2046(01)00131-1

Dede Korkut kitabi. (1994) Geris-metin-faksimile. Prof. Dr. Muharram ergun. - Ankara.

Fuad Köprülü. (1989) Edebiyat araştirmalari. - Istanbul: Ötüken.

Grinzer P.A. (1974) Ancient Indian epics. - Moscow.

Jirmunsky V. M. Zaripov H. (1947) Uzbek folk heroic epic. - Moscow.

Jirmunsky V.M. (1979) Legend of the vocation of the singer // Comparative literary criticism: East and West. Leningrad: Nauka.

Kanratbaev A. (1971) Ancient Turkic poetry and Kazakh folklore. Autotref. Diss. for the degree of Doctor of Philological Sciences. - Alma-Ata.

Link, F. H. (1980). Translation, adaptation and interpretation of dramatic texts. In The Languages of Theatre (pp. 2450). Pergamon. https://doi.org/10.1016/B978-0-08-025246-9.50010-8

McCain, R. (2006). Defining cultural and artistic goods. Handbook of the Economics of Art and Culture, 1, $147-167$. https://doi.org/10.1016/S1574-0676(06)01005-2

Mirzaev T. (1979) An epic repertoire of folk singers. - Tashkent. "Fan".

Muharrem Ergun. (1994) Dede Korkut kitabi. Giris.Tarihi kaynaklerda Dede Korkut. - Ankara.

Mulla Ghoyib. Manuscript. Inventor №1268

Mulla Ghoyib. Manuscript. Inventor №1677.

Mulla Ghoyib. Manuscript. Inventor №3.

Mulla Ghoyib. Manuscript. Inventor №7319.

Mulla Ghoyib. Manuscript. Inventor №932.

Rohrer, T. (2005). Mimesis, artistic inspiration and the blends we live by. Journal of Pragmatics, 37(10), 1686-1716. https://doi.org/10.1016/j.pragma.2005.01.015 